\title{
EVALUASI WAKTU PELAKSANAAN PEKERJAAN PADA PROYEK PEMBANGUNAN GEDUNG BAPPEDA PROVINSI KALIMANTAN UTARA TAHAP III
}

\author{
Sepry Rantesalu \\ Jurusan Teknik Sipil, Universitas Kaltara, Tanjung Selor 77212 \\ E-mail :sepry77@gmail.com
}

\begin{abstract}
ABSTRAK
Proyek pada umumnya memiliki batas waktu (deadline), artinya proyek harus diselesaikan sebelum atau tepat pada waktu yang telah ditentukan. Berkaitan dengan masalah proyek ini maka keberhasilan pelaksanaan sebuah proyek tepat pada waktunya merupakan tujuan yang penting baik bagi pemilik proyek maupun pelaksana proyek (kontraktor). Penelitian ini menganalisis evaluasi waktu pelaksanaan pekerjaan pada kegiatan Pembangunan Gedung BAPPEDA Provinsi Kalimantan Utara Tahap III untuk memberikan kontribusi biaya paling rendah dengan waktu penyelesaian lebih cepat dengan Metode Project Evaluation and Review Technique (PERT). Penjadwalan dengan menggunakan metode PERT, proyek Pembangunan Gedung BAPPEDA Provinsi Kalimantan Utara Tahap III, paling cepat dapat diselesaikan selama 178 hari dengan kemungkinan 0,001\%, paling la mbat dapat diselesaikan selama 252 hari dengan kemungkinan 99,97\%, paling mungkin diselesaikan selama 218 hari dengan kemungkinan $50 \%$.
\end{abstract}

Kata kunci: Proyek, Evaluasi, Waktu, Kontribusi, Metode PERT

\section{PENDAHULUAN}

Proyek pada umumnya memiliki batas waktu (deadline), artinya proyek harus diselesaikan sebelum atau tepat pada waktu yang telah ditentukan. Berkaitan dengan masalah proyek ini maka keberhasilan pelaksanaan sebuah proyek tepat pada waktunya merupakan tujuan yang penting baik bagi pemilik proyek maupun kontraktor.

Demi kelancaran jalannya sebuah proyek dibutuhkan manajemen yang akan mengelola proyek dari awal hingga proyek berakhir, Manajemen proyek mempunyai sifat istimewa, dimana waktu kerja manajemen dibatasi oleh jadwal yang telah ditentukan (Hartawan, n.d). Perubahan kondisi yang begitu cepat menuntut setiap pimpinan yang terlibat dalam proyek untuk dapat mengantisipasi keadaan, serta menyusun bentuk tindakan yang diperlukan.

Proyek Pembangunan Gedung BAPPEDA Provinsi Kalimantan Utara Tahap III meliputi 16 (enam belas) aktivitas, yakni Pekerjaan Persiapan, Pekerjaan Struktur dan Fasilitas, Pekerjaan Lantai dan Dinding, Pekerjaan Plafond, Pekerjaan Finishing dan Lain-Lain, Pekrjaan Outdoor, Pekerjaan Generator Set, Pekerjaan Lift Penumpang, Pekerjaan Listrik dan Penangkal Petir, Pekerjaan FireAlarm, Pekerjaan Telephone dan Tata Suara, Pekerjaan CCTV, Pekerjaan Pemandam Kebakaran, Pekerjaan Plumbing, Pekerjaan Ventilasi dan Air Conditioning. PT. Kayan Lestari dan PT. Idee Murni Pratama adalah perusahaan jasa kontraktor yang mengerjakan proyek Pembangunan Gedung BAPPEDA Provinsi Kalimantan Utara Tahap III.

Dalam penelitian ini yaitu Evaluasi Waktu Pelaksanaan Pekerjaan Pada Kegiatan Pembangunan Gedung BAPPEDA Provinsi Kalimantan Utara Tahap III menggunakan metode penjadwalan Project Evaluation Review Technique (PERT). Salah satu kelebihan metode PERT yaitu metode ini dapat membantu kontraktor dalam mengetahui berapa probabilitas terjadinya pencapaian waktu yang diinginkan. Penelitian ini diharapkan dapat membantu kontraktor dalam pembuatan jadwal proyek yang efisien dengan menggunakan Metode PERT dan dapat memberi pedoman pada kontraktor dalam melakukan evaluasi dan review terhadap jadwal proyek yang telah dibuat.

\section{STUDIPUS TAKA}

Menurut Soeharto (1999, h.2) Kegiatan proyek dapat diartikan sebagai satu kegiatan sementara yang berlangsung dalam jangka waktu terbatas, dengan alokasi sumber daya tertentu dan dimaksudkan untuk menghasilkan produk atau deliverable yang kriteria mutunya telah digariskan dengan jelas.

Munawaroh (2003) menyatakan proyek merupakan bagian dari program kerja suatu organisasi yang sifatnya temporer untuk mendukung pencapaian tujuan organisasi, dengan memanfaatkan sumber daya manusia maupun non sumber daya manusia. 


\subsection{Manajemen Proyek}

Jalan adalah seluruh bagian jalan, termasuk bangunan pelengkap dan perlengkapannya yang diperuntukkan bagi lalu lintas umum, yang berada pada permukaan tanah, di atas permukaan tanah, di bawah permukaan tanah dan/atau air, serta diatas permukaan air kecuali jalan rel dan jalan kabel (Peraturan Pemerintah No. 32 Tahun 2011).

H. Kerzner (dikutip oleh Soeharto, 1999) menyatakan, melihat dari wawasan manajemen, bahwa manajemen proyek adalah merencanakan, mengorganisir, memimpin, dan mengendalikan sumber daya perusahaan untuk mencapai sasaran jangka pendek yang telah ditentukan.

Berbeda dengan definisi H. Kerzner (dikutip oleh Soeharto, 1999), Project Management Institute (PMI) (dikutip oleh Soeharto, 1999), mengemukakan definisi manajemen proyek sebagai berikut: Manajemen proyek adalah ilmu dan seni yang berkaitan dengan memimpin dan mengkoordinir sumber daya yang terdiri dari manusia dan material dengan menggunakan tehnik pengelolaan modern untuk mencapai sasaran yang telah ditentukan, yaitu lingkup, mutu, jadwal, dan biaya, serta memenuhi keinginan para stake holder.

Project Evaluation and Review Technique adalah sebuah model Management Science untuk perencanaan dan pengendalian sebuah proyek (Siswanto, 2007). Bila CPM memperkirakan waktu komponen kegiatan proyek dengan pendekatan deterministik satu angka yang mencerminkan adanya kepastian, maka PERT direkayasa untuk menghadapi situasi dengan kadar ketidakpastian (uncertainty) yang tinggi pada aspek kurun waktu kegiatan (Soeharto, 1999). Menurut Heizer dan Render (2005), dalam PERT digunakan distribusi peluang berdasarkan tiga perkiraan waktu untuk setiap kegiatan, antara lain waktu optimis, waktu pesimis, dan waktu realistis.

\subsection{Jaringan Kerja}

Network planning (jaringan kerja) pada prinsipnya adalah hubungan ketergantungan antara bagian-bagian pekerjaan yang digambarkan atau divisualisasikan dalam diagram network. Dengan demikian dapat dikemukakan bagianbagian pekerjaan yang harus didahulukan, sehingga dapat dijadikan dasar untuk melakukan pekerjaan selanjutnya dan dapat dilihat pula bahwa suatu pekerjaan belum dapat dimulai apabila kegiatan sebelumnya belum selesai dikerjakan.

Menurut Hamilton (1997) tiga hal yang perlu diperhatikan dalam menyusun urutan aktivitas adalah:

1. Predecessor, yaitu aktivitas sebelum atau yang mendahului aktivitas yang bersangkutan, misalnya aktivitas pembersihan lahan merupakan predecessor aktivitas surveyor.

2. Successor/ followers, yaitu semua aktivitas sesudah atau yang terjadi setelah aktivitas yang bersangkutan, misalnya aktivitas surveyor merupakan successor aktivitas pembersihan lahan.

3. Concurrent, yaitu aktivitas-aktivitas yang dapat terjadi atau berlangsung bersamaan dengan aktivitas yang bersangkutan.
Penjelasan dari Predecessor, Successor, Concurrent dapat dilihat pada Gambar 1.

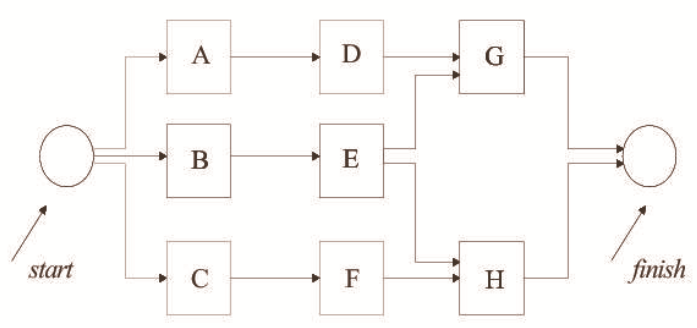

Gambar 1. Urutan aktivitas

Sebagai contoh, kita a mbil aktivitas E maka,

- Aktivitas B adalah predecessor dari aktivitas E.

- Aktivitas Gdan H adalah successor dari aktivitas E.

- Aktivitas D dan F adalah concurrent dari aktivitas E.

Hubungan antar aktivitas proyek dapat dinyatakan dengan finish to start, start to start, finish to finish, start to finish, dengan lag dapat dilihat pada Gambar 2.

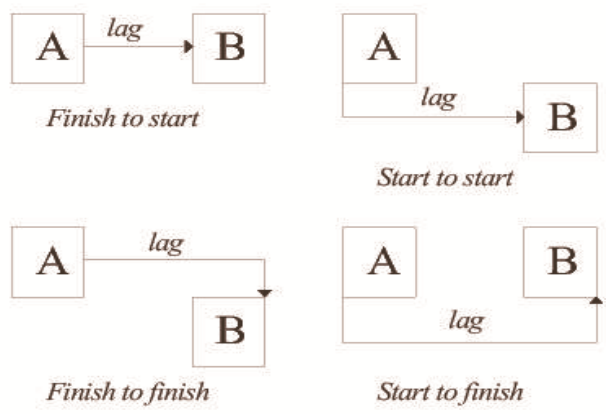

Gambar 2. Hubungan antara aktivitas

Dari Gambar 2., menunjukkan contoh hubungan antara 2 aktivitas, yaitu aktivitas A dan aktivitas B scbagai berikut :

1. Finish to start (FS)

Hubungan finish to start antara aktivitas A dan B adalah hubungan aktivitas dimana aktivitas B dapat dimulai setelah aktivitas A selesai dikerjakan.

2. Start to start (SS)

Hubungan start to start antara aktivitas A dan B adalah hubungan aktivitas dimana ketika aktivitas A dimulai maka aktivitas B juga dapat dimu lai.

3. Finish to finish (FF)

Hubungan finish to finish antara aktivitas A dan B adalah hubungan aktivitas dimana aktivitas A dan aktivitas B selesai pada waktu yang sama.

4. Start to Finish (SF)

Hubungan start to finish antara aktivitas A dan B adalah hubungan aktivitas dimana ketika aktivitas A dimulai maka aktivitas B sudah selesai.

5. Lag

Lag adalah jumlah waktu diantara mulai atau selesainya aktivitas A dengan mulai atau selesainya aktivitas B. yang dapat bernilai positif atau negatif. 


\subsection{Lintasan Kritis}

Heizer dan Render (2005) menjelaskan bahwa dalam melakukan analisis jalur kritis, digunakan dua proses twopass, terdiri atas forward pass dan backward pass. Dalam metode Critical Path Method - Metode Jalur Krit is (CPM) dikenal dengan adanya jalur kritis, yaitu jalur yang memiliki rangkaian komponen-komponen kegiatan dengan total ju mlah waktu terlama.

Jalur kritis terdiri dari rangkaian kegiatan kritis, dimulai dari kegiatan pertama sampai pada kegiatan terakhir proyek (Soeharto, 1999). Lintasan kritis (Critical Path) melalui aktivitas-aktivitas yang jumlah waktu pelaksanaannya paling lama. Jadi, lintasan kritis adalah lintasan yang paling menentukan waktu penyelesaian proyek secara keseluruhan, digambar dengan anak panah tebal (Badri, 1997).

\subsection{Probabilitas PERT}

Untuk menggambarkan variasi waktu aktivitas dalam jaringan kerja PERT, digunakan deviasi standar waktu aktivitas. Karena ada tiga perkiraan waktu untuk tiap aktivitas, maka dapat dihitung deviasi standar untuk aktivitas tersebut. Perbedaan antara waktu A dan waktu B menggambarkan jarak dari ujung ekstrim sebelah kiri ke ujung ekstrim sebelah kanan pada distribusi kemungkinan waktu kegiatan jaraknya \pm 3 deviasi standar. Dapat dirumuskan menjadi :

$$
\mathrm{S}=\frac{\mathrm{b}-\mathrm{a}}{6}
$$

Dimana:

$\mathrm{S}$ : deviasi waktu kegiatan

a : waktu optimis

b : waktu pesimis

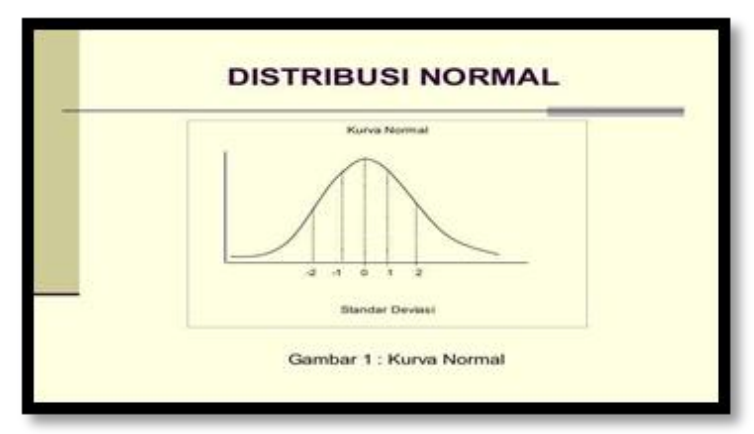

Gambar 3. Kurva distribusi normal

\section{METODOLOGI}

\subsection{Jenis dan Sumber Data}

Menurut Indriantoro (2002), sumber data dibedakan menjadi dua golongan, yaitu: 1) Data Primer, yaitu wawancara dan observasi. 2) Data Skunder, yaitu data yang diambil dariperusahaan berupa dokumen, catatan, laporanlapora, buku-buku, artikel dan berbagi publikasi serta instansi terkait yang relevan dengan masalah yang diangkat.

\subsection{Metode Analisis}

Penelitian ini menganalisis evaluasi waktu pelaksanaan pekerjaan pada kegiatan Pembangunan Gedung BAPPEDA Provinsi Kalimantan Utara Tahap III untuk memberikan kontribusi biaya paling rendah dengan waktu penyelesaian lebih cepat dengan Metode PERT.

\subsection{Analisis dengan Metode PERT}

Untuk mencapai tujuan penelitian digunakan metode PERT untuk menghitung durasi tiap-tiap pekerjaan dari data yang telah didapat dari proses sebelumnya. Langkah-langkah perhitungan dengan metode PERT adalah sebagai berikut:

1. Perhitungan Expected Time

Triple duration estimate, yaitu cara perkiraan waktu yang didas arkan atas tiga jenis durasi waktu, yaitu :

- waktu optimis (a), dugaan waktu tersingkat untuk menyelesaikan kegiatan bila segala sesuatunya berjalan tanpa hambatan sedikitpun.

- waktu paling mungkin (m), dugaan waktu yang paling sering terjadi dibandingkan dengan yang lainnya bila berulang-ulang dengan kondisi yang hampir sama.

- waktu pesimis (b), dugaan waktu yang paling lama untuk menyelesaikan kegiatan bila segalanya ada hambatan.

2. Hubungan ketergantungan antara kegiatan.

Pada tahap ini ditentukan hubungan tiap kegiatan dengan kegiatan lainnya. Menyusun urutan atau hubungan antar kegiatan berdasarkan urutan ketergantungan.

3. Menyusun digram jaringan kerja Metode PERT.

Setelah predeccesors dari setiap aktivitas ditentukan maka selanjutnya dibuat digram jaringan kerja metode PERT. Pada diagram network ini durasi tiap pekerjaan yang digunakan adalah durasi pekerjaan rencana dari expected time (te) yang telah didapatkan dari proses sebelumnya.

Berdasarkan lintasan kritis yang telah didapat pada perhitungan, kemudian tentukan nilai deviasi standard dan varians pada proyek secara keseluruhan:

$$
S=\frac{b-a}{6}
$$

Dimana:

$\mathrm{S}$ : deviasi waktu kegiatan

a : waktu optimis

b : waktu pesimis 


\section{ANALIS IS DAN PEMB AHASAN}

Hasil perhitungan waktu dari pengolahan data dengan Metode PERT ditampilkan pada Tabel 1.

Tabel 1. Perhitungan expected time

\begin{tabular}{|c|c|c|c|c|c|}
\hline \multirow{2}{*}{ Uraian Aktivitas } & \multirow[b]{2}{*}{ Simbol } & \multicolumn{3}{|c|}{ Waktu } & \multirow[b]{2}{*}{ Te } \\
\hline & & $\mathbf{t a}$ & $\mathbf{t m}$ & tb & \\
\hline PEKERJAAN PER SIAPAN & A & 15 & 25 & 25 & 25.00 \\
\hline PEK. STRUKTUR \& FASILITAS & B & 55 & 85 & 120 & 90.00 \\
\hline PEKERJAAN LANTAI \& DINDING & c & 55 & 85 & 121 & 90.00 \\
\hline PEKERJAAN PLAFOND & $\mathrm{D}$ & 50 & 80 & 146 & 85.00 \\
\hline PEK, FINISHING DAN L AIN-LAIN & $\mathbf{E}$ & 30 & 60 & so & 58.33 \\
\hline PEKERJAAN OUT DOOR & $\mathrm{F}$ & 30 & 60 & so & 60.00 \\
\hline PEKERJAAN GENERAL TOR SET & $\mathbf{G}$ & 15 & 30 & 35 & 28.33 \\
\hline LIFT PENUMPANG & $\mathbf{H}$ & 20 & 30 & 45 & 30.83 \\
\hline PEK, IISTRIK DAN PENANGKAI & $\mathrm{I}$ & 30 & 66 & 70 & 60.67 \\
\hline PEKERJAANFIRE AL ARM & $\mathbf{J}$ & 15 & 22 & 26 & 21.5 \\
\hline PEK. TELEPONE \& DATA COMP & $\mathrm{K}$ & 35 & 46 & 50 & 44.8 \\
\hline PEKERJAAN TATA SUARA & $\mathbf{L}$ & 30 & 45 & so & 43.33 \\
\hline PEKERJAAN CCTV & $\mathbf{M}$ & 20 & 30 & 35 & 29.17 \\
\hline PEK. PEMADAM KEBAKARAN & $\mathbf{N}$ & 30 & 45 & so & 43.33 \\
\hline PEKERJAAN PLUMBING & 0 & 30 & 45 & 60 & 45.00 \\
\hline $\begin{array}{l}\text { PEK. MEK ANIKAI VENTILASI } \\
\text { DAN AIR CONTIONING }\end{array}$ & $\mathbf{P}$ & 30 & 60 & so & 58.33 \\
\hline
\end{tabular}

Untuk membuat Jalur Kritis pada Diagram Jaringan Kerja Metode PERT maka dibutuhkan hubungan ketergantungan item peke rjaan ditampilkan pada Tabel 2.

Tabel 2. Hubungan ketergantungan item pekerjaan

\begin{tabular}{|c|c|c|c|c|c|c|c|}
\hline \multirow[b]{2}{*}{ No } & \multirow[b]{2}{*}{ Craian Aktivitas } & \multirow[b]{2}{*}{ Pendatuluan } & \multirow[b]{2}{*}{ Lanjutan } & \multicolumn{3}{|c|}{ Waktu } & \multirow[b]{2}{*}{ Ie } \\
\hline & & & & $\begin{array}{c}\mathrm{Ta} \\
\text { (Optimis) }\end{array}$ & $\begin{array}{c}\text { Tm } \\
\text { (Mug gkin) }\end{array}$ & $\begin{array}{c}\mathrm{Tb} \\
\text { (Pesimis) }\end{array}$ & \\
\hline 1 & PEKERJAAN PERSIAPAN & A & B.C & 15 & 25 & 35 & 25.00 \\
\hline 2 & PEK. STRUKTUR \& FASILITAS & B & D.E & 60 & 90 & 120 & 90.00 \\
\hline 3 & PEKERJAAN LANTAI \& DINDING & c & 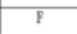 & 60 & 90 & 120 & 90,00 \\
\hline 4 & PEKERJAAN PLAFOND & D & 0 & 50 & 80 & 140 & 85.00 \\
\hline 3 & PEK. FINISHING DAN LAIN-LAIN & $\bar{E}$ & H & 30 & 60 & 80 & 58.33 \\
\hline 6 & PEKERJAAN OUT DOOR & $F$ & $t$ & 30 & 60 & 90 & 60,00 \\
\hline 7 & PEKERJAAN GENERAL TOR SET & $\theta$ & J & 13 & 30 & 35 & 28.33 \\
\hline 8 & LIFT PENUMPANG & H & $\bar{K}$ & 20 & 30 & ts & 30.83 \\
\hline 9 & PEK. LISTRIK DAN PENANGKAL & $t$ & $\mathrm{t}$ & 30 & 66 & 70 & 60.67 \\
\hline 10 & PEKERJAANFIRE ALARM & 1 & $\mathrm{M}$ & 15 & 22 & 26 & 21.50 \\
\hline 11 & PEK. TELEPONE \& DATA COMP & K & $\mathrm{N}$ & 35 & 46 & 50 & 44.83 \\
\hline 12 & PEKERJAAN TATA SUARA & $\mathrm{L}$ & $\mathrm{N}$ & 30 & 45 & 50 & 43.33 \\
\hline 13 & PEKERJAAN CCTV & M & 0 & 20 & 30 & 35 & 29,17 \\
\hline 14 & PEK. PEMADAM KEBAKARAN & $\mathrm{N}$ & 0 & 30 & 45 & 90 & 43.33 \\
\hline 15 & PEKERJAAN PLUMBING & 0 & $P$ & 30 & 45 & 60 & 45.00 \\
\hline 16 & PEK. MEKANIKAL VENTILASI & $P$ & & 30 & 60 & 80 & 38,33 \\
\hline
\end{tabular}

Dari ketergantungan item pekerjaan, maka dibuat Diagram Jaringan Kerja Metode PERT untuk mengetahui jalur kritis dari suatu kegiatan yang ditampilkan pada Gambar 3. sebagai berikut:

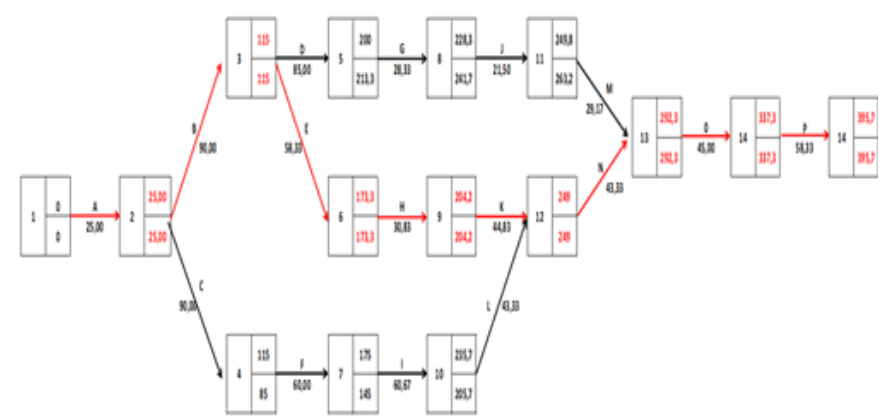

Hasil analisis penjadwalan dengan Metode PERT dengan nilai te sebagai durasi yang digunakan dalam perhitungan diperoleh Jalur Kritis pada Diagram Jaringan Kerja pada kegiatan adalah :

A-B-E-H-L-N-O-P

Maka:

$$
\begin{aligned}
\sigma & =\sqrt{ } \mathrm{A}+\mathrm{B}+\mathrm{E}+\mathrm{H}+\mathrm{L}+\mathrm{N}+\mathrm{O}+\mathrm{P} \\
& =\sqrt{ } 395,67 \\
& =19,9
\end{aligned}
$$

Setelah menghitung Jalur Kritis, kemudian tentukan nilai Deviasi Standard dan Varians pada Proyek secara keseluruhan dengan rumus : $\mathrm{S}=\frac{\mathrm{b}-\mathrm{a}}{6}$

Nilai varians kegiatan dapat dicari dengan rumus:

$\mathrm{V}=(\mathrm{te})=\mathrm{S} 2$

Maka kedua variable tersebut dapat dilihat dalam Tabel 3.

\begin{tabular}{|c|c|c|c|c|c|}
\hline Uraian Aktivitas & Simbol & $\begin{array}{c}\text { ta } \\
(\text { Hari) }\end{array}$ & $\begin{array}{c}\text { tm } \\
\text { (Hari) }\end{array}$ & s & $V(t \mathrm{te})$ \\
\hline PEKERUAMN PERSISPAN & A & 15,00 & 25,00 & 1,67 & 2,78 \\
\hline PEK. SIRUKIUR DAN BANGFASILITAS & B & 60,00 & 90,00 & 5,00 & 25,00 \\
\hline PERERUMAN FINISH ING / LAIN-LAIN & E & 30,00 & 60,00 & 5,00 & 25,00 \\
\hline LHFT PENUMPANG & $\mathrm{H}$ & 20,00 & 30,00 & 1,67 & 2,78 \\
\hline PEKERUMAN TATA SUARA & $\mathrm{N}$ & 30,00 & 45,00 & 2,50 & 6,25 \\
\hline PEKЕRUAN PEMADMM KЕВAKARAN & L & 30,00 & 45,00 & 2,50 & 6,25 \\
\hline PEEKUMAN PLUMMBING & 0 & 30,00 & 45 & 2,50 & 6,25 \\
\hline $\begin{array}{l}\text { PEK. MEKANIKAL VENIHLASL, DAN AIR } \\
\text { CONIONING }\end{array}$ & $P$ & 30,00 & 60,00 & 5,00 & 25,00 \\
\hline$\sum V(t e)$ & \multicolumn{5}{|c|}{99,31} \\
\hline Standar Deriasi & \multicolumn{5}{|c|}{9,97} \\
\hline
\end{tabular}
sebagai berikut:

Tabel 3. Nilai standard deviasi dan varians kegiatan

Dari Tabel 3. Di atas dapat diketahui nilai total varians $(\Sigma$ $\mathrm{V}(\mathrm{te}))=99,31$ dan deviasi standar $(\mathrm{S})=9,97$ dengan penyelesaian proyek paling cepat adalah $=178$ hari. Dan perkiraan penyelesaian proyek paling lambat adalah $=218$ hari. Jika dalam hal ini target yang ingin dicapai adalah kurun waktu yang paling cepat, maka nilai $\mathrm{T}(\mathrm{d})=178$ hari. Kemungkinan/ketidakpastian mencapai target jadwal pada metode PERT dinyatakan dengan z:

$$
\begin{aligned}
\text { Deviasi } \mathrm{Z} & =(\mathrm{T}(\mathrm{d})-\mathrm{Te}) / \mathrm{S} \\
& =(178-218) / 9,97 \\
& =-3,98
\end{aligned}
$$

Hasil selengkapnya perhitungan Target dan Kemungkinan Penyelesaiaan Proyek dapat dilihat pada Tabel 4.

Gambar 3. Diagram jaringan kerja 
Tabel 4. Hasil perhitungan target dan kemungkinan penyelesaian proyek

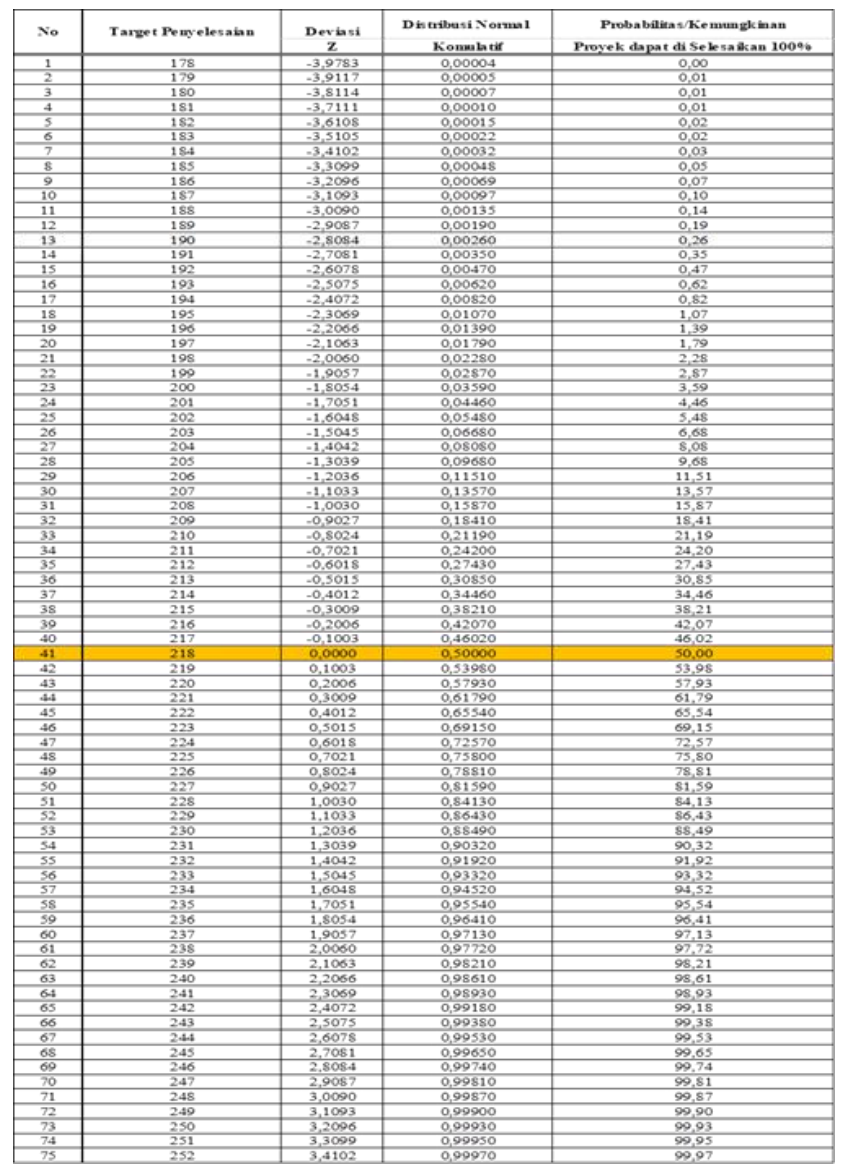

Dari hasil perhitungan Target dan Kemungkinan Penyelesaiaan Proyek diperoleh Kurva Probabilitas:

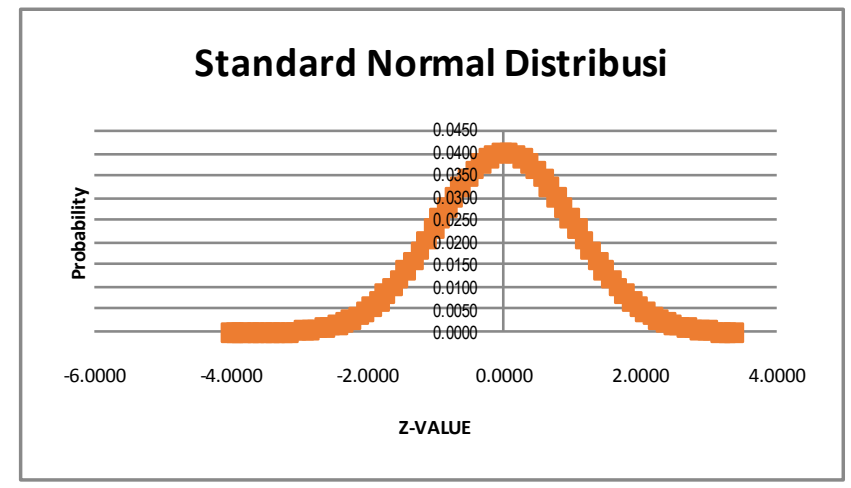

Gambar 4. Kurva Probabilitas
Dari hasil analisis diatas dapat diketahui bahwa:

1. Kemungkinan proyek dapat diselesaikan dalam waktu 178 hari adalah $0.001 \%$.

2. Kemungkinan proyek dapat diselesaikan dalam waktu 218 hari adalah $50 \%$.

3. Kemungkinan proyek dapat diselesaiakan dalam waktu 252 hari adalah $99.97 \%$

\section{KES IMPULAN}

Berdasarkan analisis data dari hasil penelitian dan uraianuraian yang didapat dari pembahasan dan analisis, maka dapat ditarik kesimpulan bahwa penjadwalan dengan menggunakan Metode PERT, proyek Pembangunan Gedung BAPPEDA Provinsi Kalimantan Utara Tahap III, paling cepat dapat diselesaikan selama 178 hari dengan kemungkinan 0,001 \%, paling lambat dapat diselesaikan selama 252 hari dengan kemungkinan 99,97\%, paling mungkin diselesaikan selama 218 hari dengan kemungkinan $50 \%$.

\section{DAFTAR PUS TAKA}

Badri, S. (1997). Dasar-Dasar Network Planing, PT Rika Cipta, Jakarta.

Bennatan, E.M. (1995). One Time within Budget: Software Project Management Practice and Techniques, John Wiley and Sons, Inc, New York.

Handoko, T.H.. 1999. Dasar-dasar Manajemen Produksi Dan Operasi, Edisi Pertama. BPFE : Yogyakarta.

Hayun, Anggara. 2005. "Perencanaan dan Pengendalian Proyek dengan Metode PERT-CPM: Studi Kasus Fly Over Ahmad Yani, Karawang." Journal The Winners, Vol. 6, No.2, h. 155-174.

Martami Budi dan Gunawan Robby. (2002). Penentuan Produktivitas Tenaga Kerja Pada Proyek Gudang Struktur Baja Berdasarkan Durasi PERT. Skripsi. Jurusan Teknik Sipil, Fakultas Teknik Sipil dan Perencanaan, Universitas Kristen Petra: Surabaya

Soeharto, Imam. (1995). Manajemen Proyek: Dari Konseptual sampai Operasional. Erlangga: Jakarta.

Wulfram, I. Ervianto. (2004). Teori Aplikasi Manajemen Proyek Konstruksi. Andi offset: Yogyakarta. 